\title{
Investigating Determinants of Student Satisfaction in the First Year of College in a Public University in the State of Qatar
}

\author{
Bothaina Al-Sheeb ${ }^{D},{ }^{1}$ Abdel Magid Hamouda, ${ }^{2}$ and Galal M. Abdella ${ }^{3}$ \\ ${ }^{1}$ Business Services Coordinator, Qatar Foundation, Doha, Qatar \\ ${ }^{2}$ Acting Dean of College of Engineering, Qatar University, Doha, Qatar \\ ${ }^{3}$ Assistant Professor of Quality Management, Qatar University, Doha, Qatar \\ Correspondence should be addressed to Bothaina Al-Sheeb; 200669067@qu.edu.qa
}

Received 10 August 2018; Accepted 20 September 2018; Published 8 November 2018

Academic Editor: Gérard Lassibille

Copyright (c) 2018 Bothaina Al-Sheeb et al. This is an open access article distributed under the Creative Commons Attribution License, which permits unrestricted use, distribution, and reproduction in any medium, provided the original work is properly cited.

\begin{abstract}
Purpose. A first-year student's life is a web of interrelated academic and social experiences. Most universities have rigorous processes to achieve excellence or reach high-quality standards, with "Student Satisfaction" being the central focus of all of higher education aims for excellence. This study examined the influence of various academic, social, and environmental aspects on the overall satisfaction of first-year students. Design. A questionnaire was designed and administered to first-year students, and the resulting data were analyzed using correlation, linear regression, binary logistic regression, and artificial neural networks. Findings. The findings suggested that three of the five factors explored-100-level course satisfaction, a sense of belonging, and citizenship knowledge and skills-were the best determinants of the level of first-year student satisfaction. Originality. This study examined the influence of academic, social, and environmental factors on overall student satisfaction with the college experience. Many studies have focused on how factors such as student attitudes, perceptions, and academic and social engagements impact first-year student success and retention; however, few studies have attempted to explore the influence these factors have on student satisfaction and their overall perceptions of the college experience. Discussion and Conclusion. This study has provided a snapshot of some of the key determinants of the overall student satisfaction of the first-year experience. This study can assist college administrators and instructors in their quality assurance initiatives which may include reviewing the current system, setting college priorities, and planning and allocation of future resources to better achieve higher levels of student satisfaction.
\end{abstract}

\section{Introduction}

First-year student retention and success is challenging for many higher education institutions. Many universities around the world including Qatar University have made significant changes to their admissions policies, which have resulted in significantly larger first-year intakes. For universities to fulfill their role of developing their nation's economies by improving student success and retention, it is necessary to determine the factors that contribute to overall student satisfaction. To this end, ensuring that first-year students graduate is a critical issue for this university, as it is for many higher education institutions. One of the major strategies adopted by this institution was to implement a "first-year experience" initiative to assist first-year students to adapt to college life and to give guidance to those who are underperforming. The "first-year experience" initiative has included programs and activities such as student orientations, first-year seminars, and success workshops. An important part of this initiative was to measure and explore the five factors contributing to overall first-year student satisfaction. A questionnaire was designed to provide a snapshot of overall student satisfaction and to assess the correlation with the three dimensions and five identified factors: academic (course effectiveness and citizenship knowledge and skills), social (a sense of belonging and interaction with key college members), and environmental (student awareness and utilization of campus resources). These factors, which were based on Astin's interaction theory and Tinto's model of departure, have been found to be the most important 
elements in first-year college life. This study sought to gain a greater insight into the contributions these factors had on overall first-year student satisfaction. To achieve this aim, the questionnaire was administered to 282 first-year students, and the resulting data were analyzed using regression analysis and artificial neural networks. In line with previous research, it was found that student course ratings were the best predictors of overall college satisfaction, with student citizenship knowledge and skills and a sense of belonging also found to be highly correlated. In contrast to previous research, however, this study found that student interactions with key members such as faculty, school administrators/staff, and other students and an awareness and utilization of campus resources were not highly correlated with overall student satisfaction.

\section{Literature Review}

2.1. Definition of Student Satisfaction. Student satisfaction definitions have varied widely depending on the research approach and focus. In this study, student satisfaction was examined from an educational perspective. Elliott and Healy [1] defined student satisfaction as a "short-term attitude resulting from an evaluation of a student's educational experience" (p. 2) and claimed that student satisfaction was achieved when their actual experiences or performances met or exceeded their initial expectations. Aldridge and Rowley [2] divided student satisfaction evaluations into two categories, with the first being focused on classroom teaching and learning evaluation and the second being focused on the comprehensive student experience. For the purpose of this study, student satisfaction was defined as student happiness or contentment with their overall college experience. Student satisfaction was assessed based on the extent of positive ratings given to the education quality at the institution, the overall college experience, whether students would choose to register again at the same college if they had the choice to start over, and whether the other courses they took had assisted them to adapt to college life; therefore, this definition combined a measure of both overall student satisfaction and the intention to persist.

This study used a selective student satisfaction evaluation model in which certain student satisfaction determinants linked to the college learning outcomes for successful firstyear experiences were explored. This model is described in more detail in Conceptual Framework.

\subsection{Importance of Student Satisfaction in Higher Education}

2.2.1. Accountability. Student satisfaction is a major concern for higher education institutions. Bryant and Bodfish [3] claimed that student satisfaction was a major performance indicator for higher education institutions, with many universities implementing rigorous quality assurance processes. Browne et al. [4] noted also that the goal of many universities was to improve accountability by "streamlining processes and improving services to students, faculty, and staff" (p.1). There have been several studies on the links between student satisfaction and higher education service quality [5-8]. However, many studies have argued that the customer concept in higher education has not yet been clearly defined (e.g., Marzo Navarro et al. [9]), "which makes these institutions difficult to manage from a marketing point of view." Elliot [10] believed that evaluating student satisfaction was a daunting task due to the complex nature of higher education and because of the "confusion concerning students as customers" (p. 2).

\subsubsection{Decrease of Student Attrition and Loss of Resources.} Another important reason that student satisfaction is of importance is that dissatisfied students often withdraw during their first year at college. From a financial perspective, it has been found that retaining students is more efficient than recruiting new students. Tinto [11] found that a failure to retain current students was a waste of both human and financial resources and was a primary concern for major stakeholders such as higher education leadership students and parents. Elliot [10] also claimed that many universities were aware that it was more efficient to "invest now (retain students) than to invest later (attract new students)," arguing that retaining students was less costly than admitting a new one (p. 199). Schertzer and Schertzer [12] also found that as higher education students were "consumer oriented," attrition was increasing and that the failure to retain students was both costly and ineffective.

\subsubsection{Importance of the First-Year Experience Assessment.} "Student satisfaction" is one of the most important dimensions for the assessment of first-year experiences. For this reason, it is essential to explore the determinants or factors that influence overall first-year student satisfaction. It has been found that a student's perceptions and experiences during their first college year lay the foundation for future success and graduation. This notion is supported by the work of Barefoot [13]. Therefore, student evaluations of the social and academic aspects of the college community can provide institutions with important insights into the students' overall college experiences.

\subsection{Student Satisfaction Is Complex and Multidimensional.} Evaluating first-year student experiences and satisfaction is a complex process because "student life is seemingly a web of interrelated activities and experiences" (Elliott [10], p. 1). Schrader and Brown [14] believed that as educational services were complex in nature, service quality perception was based on complex interactions that require "multidimensional consideration and evaluation” (p. 161).

Previous studies have confirmed the multidimensionality of student satisfaction. Hanssen and Solvoll [15] found that student satisfaction was a multidimensional process influenced by many factors. Hartman and Schmidt [16] explored student and alumni satisfaction from a consumer perspective (a TQM principle) and found that the satisfaction ratings were influenced by the students' perceptions of both the college performance quality and the academic outcomes resulting from that performance. 
2.4. Common Student Satisfaction Surveys. Most colleges measure student satisfaction by administering student satisfaction surveys such as CIRP (Freshmen Survey), NSSE (National Survey of Student Engagement), SSI (Student Strength Inventory), and Noel Levitz survey. Billups [17] claimed that these surveys were useful to higher education leaders as they could be used to determine the areas that needed improvement as well as to propose new programs. Furthermore, as student satisfaction has often been linked to student persistence, such surveys give administrators valuable insights into how the institution's quality is perceived by the different stakeholders, which can assist in institutional strategic planning and goal setting. However, many of these surveys are costly and not readily available to college personnel.

2.5. Student Satisfaction and Student Retention. As highly satisfied students are more likely to persist in their studies and graduate, it is important to regularly evaluate student satisfaction. Schertzer and Schertzer [12] and Styron [18] explored the relationships between student satisfaction and college graduation, with Styron [18] finding that retention was correlated with several social and academic involvement factors and that students who had withdrawn had significantly lower social involvement and faculty approachability satisfaction than students who had continued with their studies.

\subsection{Student Satisfaction and Student Success/Academic} Performance. Satisfaction can motivate students to work harder, achieve success, and persist until graduation. Oja [19] found that student performance was statistically related to student satisfaction ratings for several institutional aspects. In another study, Bryant and Bodfish [3] explored student satisfaction and student graduation rates in four different higher education institutions and concluded that the higher the student satisfaction level, the higher the number of graduating students. Similarly, Dhaqane and Afrah [20] found that satisfaction promoted both academic achievement and student retention; however, Bean and Bradley's [21] examination of the "reciprocity" between satisfaction and performance found that student performance had no positive impact on overall satisfaction.

2.7. Recent Related Literature. Studies that have utilized comprehensive approaches to student satisfaction include Gruber et al. [22] and Butt and ur Rehman [23]. Gruber et al. [22] designed a student satisfaction instrument for a German university that covered fifteen dimensions such as administrative and student services, student atmosphere, the courses, and lecturer support. Similarly, Butt and ur Rehman [23] examined student satisfaction on four education dimensions: teaching expertise, the offered courses, the learning environment, and classroom facilities. Temizer and Turkyilmaz [24] developed a Student Satisfaction Index (SSI) model for higher education institutions that measured student satisfaction from different aspects such as institutional image, expectations, perceived quality, perceived value, and loyalty. In another study, Alam Malik et al. [25] explored student perceptions and expectations in a business school through the assessment of factors such as teaching expertise, the courses offered, the learning environment, and the classroom facilities and found that academic facilities were the most important aspect of overall student satisfaction; however, significant differences were found between male and female student satisfaction levels. Parahoo et al. [26] also investigated whether gender was a factor in measuring overall student satisfaction using three dependent satisfaction measures: global satisfaction, willingness to recommend the college, and satisfaction with the value they had received from their overall academic experiences, and found that university reputation was the only significant predictor for female students, while both reputation and academic faculty competence were significant for male students.

Several other studies have concentrated on specific aspects of college life. Yang et al. [27], for example, explored how classroom attributes affected student satisfaction and performance in higher education classrooms and found that student perceptions relied heavily on spatial characteristics such as visibility and furniture and ambient characteristics such as air quality and temperature, which were significantly impacted by classroom design, management, and maintenance.

Other studies have attempted to use more creative approaches to determine student satisfaction. Douglas et al. [28] assessed student experiences as being satisfying or dissatisfying from handwritten narratives by first-year and senior students that focused on the teaching and learning and the support service environment, from which a number of new overall quality determinants were identified: motivation, reward, social engagement, usefulness, value for money, and fellow student behavior. Bates et al. [29] explored student satisfaction using photographic elicitation, with the thematic analysis of the student interviews revealing that the themes related to students' satisfaction were the learning environment, work-life balance, and the wider university community.

\subsection{Factors Impacting Student Satisfaction in This Study}

2.8.1. Student 100-Level Course Ratings. Student satisfaction is usually associated with academic experience evaluations and teaching effectiveness perceptions. For example, Marzo Navarro et al. [9] concluded that student perceptions of the faculty, teaching techniques, and course administration were the key elements to student satisfaction and college loyalty. Elliot [10] examined the aspects of student academic experience that were most likely to influence student satisfaction and found that "instructional effectiveness" was a key determinant for overall student satisfaction.

2.8.2. Citizenship Knowledge and Skills. This determinant refers to the student knowledge and skills required to be a successful citizen, which we believe could influence student satisfaction. In higher education, students are expected to 
become involved in civil engagement activities. For example, at this university, students are expected to gain the knowledge, values, and skills necessary to be responsible citizens; therefore, it was expected that a student who had these positive behaviors would be motivated to graduate from college and would have a positive view toward higher education in general and toward the institution in particular. Frederick [30] defined the responsible citizen, some elements of which were a strong understanding of the nation's history and political processes, knowledge on recent events, an embracing of democratic values, and engagement in civil activities, which were divided into six elements: knowledge, values, skills, engagement, identity, and a sense of efficacy.

2.8.3. A Sense of Belonging. A sense of belonging in this study refers to feeling a part of the campus community and a commitment toward the institution. Strayhorn [31] claimed that college students' sense of belonging came from their perceptions regarding social support, a feeling of connectedness, and a feeling of being accepted, respected, and valued by others (group or campus community) (p. 4). Hurtado and Carter [32] claimed that the sense of belonging measure differed from social integration as it was related to an attachment to the campus community as a whole. Research has tended to confirm that a sense of belonging is strongly related to overall satisfaction with the college experience [33-35].

2.8.4. Interaction with Key Members. Several studies have confirmed the impact of student-faculty interactions on higher education academic and social outcomes and overall student satisfaction [36, 37]. Interactions with the college environment as a whole and with key individuals in particular have been found to shape student views on higher education and on judgments as to whether to continue. Elliot [10] and Billups [17] both found that student contact with faculty, staff, and other students had a positive impact on student decisions to continue as well as on their overall satisfaction with the college experience.

2.8.5. Awareness and Utilization of Campus Resources. This section discusses whether student knowledge and the utilization of available support services influence satisfaction with the college experience. Nasser et al. [38] examined the relationship between student knowledge on college services and programs and overall satisfaction and concluded that knowledge was a significant satisfaction factor and that "the higher the knowledge, the more satisfied the students are likely to be" (p. 1). Hanssen and Solvoll [15] examined which college facilities had the greatest impact on student satisfaction and found that the quality of social areas, the auditorium, and libraries were the most important facilities related to student satisfaction. Bryant and Bodfish [3] also found that schools with better campus facilities were more likely to have higher student satisfaction and higher graduation rates. However, there have been few studies on the relationship between actual resource utilization and student college satisfaction or perceptions of the overall quality of the college experience.

2.9. Conceptual Framework. Astin's input-environmentoutput (IEO) model and Tinto's theory of student departure formed the basis for the conceptual framework in this study.

Astin [39] claimed that student outcomes were a function of three important components: inputs (student precollege background characteristics), environment (the various experiences offered on campus: programs, policies, education, and social experiences), and outcomes (student persistence, success, and satisfaction). Figure 1 shows the adapted conceptual model.

Tinto's theory of student departure or Tinto's “Model of Institutional Departure" states that to persist, students need to be integrated into formal (academic performance) and informal (faculty/staff interactions) academic systems and formal (extracurricular activities) and informal (peer-group interactions) social systems [40]; therefore, this model states that both academic and social engagement are essential for student persistence. Burtner [41] stated that "theories of persistence" confirmed that it was the college experience, more than other precollege characteristics, which was responsible for a student's decision to stay until graduation ( $p$. 1). Similarly (as cited in Elliot and Shin [42]), Sevier [43] confirmed that "an institution's product is the sum of the student's academic, social, physical, and even spiritual experiences."

2.10. Research Gaps. This study examined the influence of several social and academic engagement factors on overall student satisfaction with the college experience; therefore, this study was not intended to evaluate student satisfaction as a whole but rather to investigate the influence of some factors on student satisfaction. The factors examined were those that have been highlighted in previous research as being essential for new students to adapt to university life. This study roughly classified these factors into three dimensions: academic (student 100-level course evaluation and citizenship skills and knowledge obtained), social (a sense of belonging and interactions with key university members), and environmental (awareness and utilization of campus resources). Many studies have focused on how factors such as student attitudes, perceptions, and academic and social engagements impact first-year student success and retention; however, few studies have attempted to explore the influence these factors have on student satisfaction and their overall perceptions of the college experience.

2.11. Research Questions. This study sought to fill a research gap and offer greater understanding of the elements that have been strongly associated with overall student satisfaction. Specifically, the study sought to answer the following research questions:

(1) What is the correlation strength to overall student satisfaction for each of the five factors? 


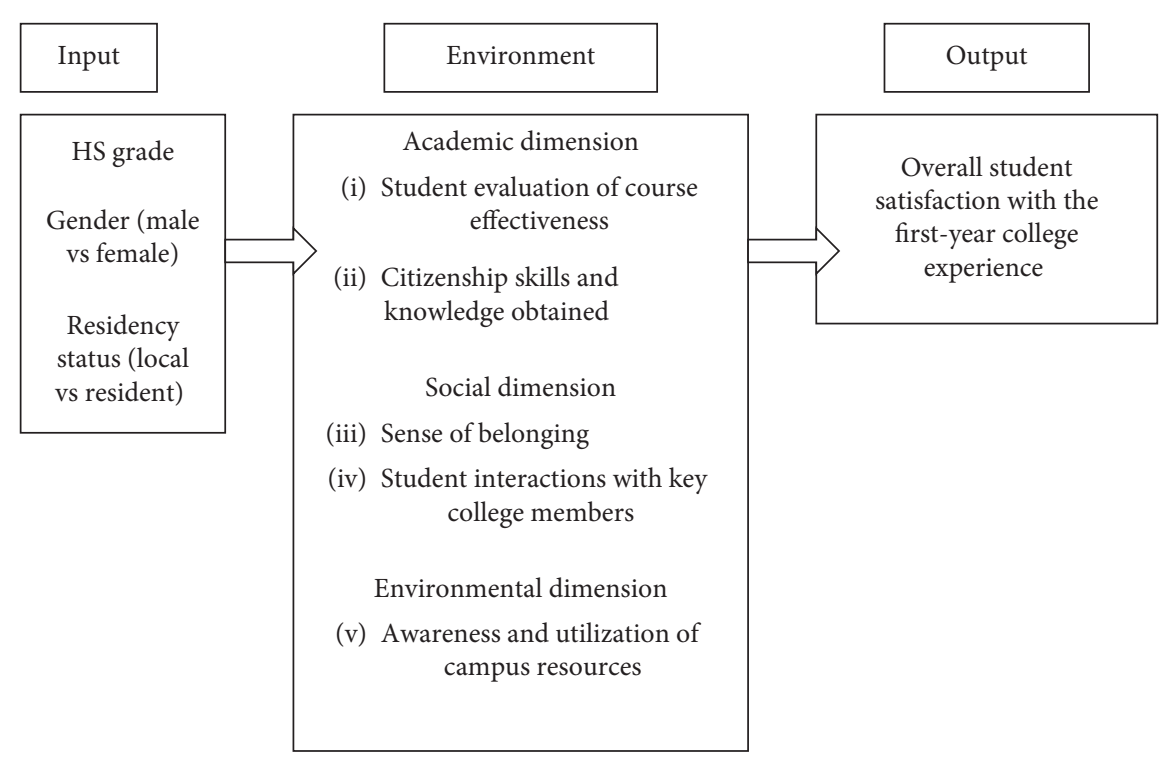

Figure 1: Conceptual model for student satisfaction adapted from Astin's I-E-O model.

(2) How do these five factors contribute to the variances in overall student satisfaction?

(3) How can binary logistic regression and artificial neural networks be used to predict overall student satisfaction (satisfied and less satisfied)? Which method provides the best overall accuracy value?

\section{Method}

3.1. Research Design and Context. This study explored the influence of the academic, social, and environmental factors on first-year college student satisfaction, for which regression and classification methods were used to explore the capacity of these factors to predict overall student satisfaction. The focus of this study was on first-year students at a public four-year institution.

3.2. Participants. A questionnaire was developed and administered to 282 first-year students during three 100-level course lectures in Spring 2014, all of which were from the five general college requirements or "core courses." In this university, core courses are part of the five high-impact practices for the first-year experience, which means that these courses have high first-year student enrolments. With an initial sample of 300 students, the overall response rate was $94 \%$.

3.3. Instrument. The questionnaire had several sections, as shown in Table 1. The first few questions gathered information about general demographics: age, gender, nationality, college, high school type, and credit hours registered. The first section focused on "course evaluation" and included statements related to several course evaluation aspects: timing, duration, content, and lesson delivery, whether the course encouraged participation and interaction, enhanced motivation and academic performance, and improved skills, and whether they would recommend the course to a friend. The second section (citizenship knowledge and skills) had five statements focused on the knowledge that participants had of the local community and development and whether they were aware of the available research funding and training opportunities. The third section had four broad statements about the students' sense of belonging focused on whether the student felt part of campus life and felt willing to continue with their education at this college. The responses for sections 1-3 were recorded on a 5-item Likert scale ranging from (1) strongly disagree to (5) strongly agree. The fourth section focused on the frequency of interaction (by phone, email, and SMS and personally) with key higher education members such as faculty, academic advisors, close friends, and teaching assistants on a six-item scale: "never," "once or twice a semester," "once or twice a month," "once a week," "two or three times a week," or "daily." Each scale was assigned a specific value to facilitate data analysis, which is shown in Table 2. The fifth section had a list of campus resources, and students were required to indicate whether they were aware of each service or the support provided on campus by selecting "yes" or "no" and also rated their frequency of use of these services by selecting "frequently," "occasionally," or "not at all."

3.4. Data Collection Procedure. Three courses: DAWA 111 "Islamic Culture," MATH 103 "Intermediate Algebra," and ENGL 110 "English I," from the 100-level courses were selected for the survey. These three courses were selected from the five courses identified by the college administration as "high-impact" practices, which meant that there was a high first-year enrolment as these were important elements of the first-year experience. An email was sent to instructors to seek permission for the researcher to administer the survey in the last 10 minutes of class time. 
TABLE 1: Items used for each variable.

Student overall satisfaction (Likert scale used: strongly agree "5"; agree "4"; neutral "3"; disagree "2"; strongly disagree "1")

Overall, I am satisfied with the quality of my first-year experience.

I think Qatar University is offering high-quality education to its students.

Other courses I registered for this semester helped me adapt to university life.

I would choose to register at QU if I had the choice to start over again.

I plan to continue to study at Qatar University.

100-level course evaluation (Likert scale used: strongly agree “5”; agree "4"; neutral “3”; disagree "2"; strongly disagree "1")

Overall course experience

Overall, I had a good experience with this course.

Timing and duration

The course session durations were adequate.

The timing of the course sessions was appropriate.

Content and lesson delivery

The content delivered in this course was adequate.

The sessions were delivered as outlined in the syllabus.

Participation in activities

This course helped me adapt to college life easily after high school.

This course helped me become aware of the various activities taking place on campus.

Interactions with others

This course encouraged me to interact both academically and socially with my classmates.

The course has increased my interactions with faculty members and staff (course instructor, academic advisor, etc.).

Motivation and academic performance

This course had increased my motivation to excel in my higher education degree.

This course has endorsed my academic performance.

Improvement in skills and awareness

The knowledge I gained in this course helped me have clear objectives about my involvement in QU.

This course has given me the opportunity to develop my writing skills.

This course has given me the opportunity to develop my presentation skills.

This course has improved my time management skills.

This course has given me the tools and skills to succeed in college.

This course has helped me recognize my career preferences.

Perceived importance

This course is important for first-year students.

Citizenship skills and knowledge (Likert scale used: strongly agree "5”; agree “4”; neutral "3"; disagree "2"; strongly disagree "1")

I have good knowledge of Qatar's National Vision 2030.

I have good knowledge of Qatar's National Development Strategy.

I am aware of the UREP* program for undergraduate students.

I plan to achieve change and development in my future career.

I know how to develop my leadership skills through the services and activities offered by QU.

Sense of belonging (Likert scale used: strongly agree "5"; agree “4”; neutral "3"; disagree "2"; strongly disagree "1")

I feel part of college campus life.

I feel responsible for my own education and learning.

I feel capable to continue my academic studies.

Interaction (scale used: never "0"; 1-2 times per semester "1"; 1-2 times per month "2"; once a week "3"; 2 -3 times per week "4"; daily “5”)

How often have you interacted with this course instructor outside class?

How often have you interacted with your other course instructors outside class?

How often have you interacted with academic advisors/counselors?

How often have you interacted with close friends at this institution?

How often have you interacted with graduate students/teaching assistants?

Awareness and utilization of support services

Are you aware of each of the following campus resources/support services? ("Yes"/"no")

How often have you utilized each of the following campus resources/support services? ("Frequently," "occasionally," and "not at all")

Printing and photocopying service

Financial aid

Transportation (e.g., campus express)

Student call center

Academic advice

Textbooks

Group therapy

Student Learning Support Center (e.g., writing labs) 
TABle 1: Continued.

\author{
Qatar University Center for Volunteer Work \\ Career services \\ Library \\ Student counsel \\ International students \\ Student employment \\ Student clubs \\ Sport activities \\ Voluntary work and community service \\ Awareness $(0,1)$ \\ Frequency of utilization $(1,2,3)$
}

TABle 2: Descriptive statistics by course and gender.

\begin{tabular}{lccccc}
\hline & \multicolumn{5}{c}{ Gender } \\
& & Male & Female & Frequency & Percent \\
\hline \multirow{4}{*}{ Course name } & ENGL 110 & 36 & 66 & 102 & 36.2 \\
& MATH 103 & 43 & 51 & 94 & 33.3 \\
Total & DAWA 111 & 26 & 60 & 86 & 30.5 \\
\hline
\end{tabular}

Participation in this paper-and-pencil survey was voluntary, and it was made clear that students do not have to answer if they had already answered the survey in another class. The survey was administered in Arabic to make it more accessible, and completed questionnaires were returned to the researcher at the end of the class.

3.5. Data Analysis Procedure. The independent variable in this study was overall student satisfaction. There were five dependent variables: course effectiveness evaluations, citizenship knowledge and skills, a sense of belonging, interaction with key college members, and awareness and utilization of campus resources.

Data were analyzed using SPSS v. 24. First, descriptive statistics were generated to gain an overall idea of the sample collected, after which Pearson's correlation coefficient was used to explore the relationships between the variables. Multiple linear regression analyses were performed to calculate the total variance in student satisfaction that could be explained by the five factors, and then the overall student satisfaction data were used to classify students based on their satisfaction level (satisfied or less satisfied). Binary logistic regression and artificial neural network predictive analytic procedures were then used to check the capabilities of the five factors to predict student satisfaction levels and to group the students into one of the two satisfaction level categories. The predictive accuracy of the two models was determined using the value of the overall percentage of correct predictions calculated by each model.

The initial analysis of the data indicated that there were no statistically significant differences based on gender (male vs female) or residency status (local vs resident). As the inclusion of gender and residency did not increase the prediction accuracy of the models, these factors were not used in the subsequent analyses.

\section{Results}

4.1. Preliminary Analysis. There were 105 males and 177 females in the sample. The sample included around $30 \%$ of the evaluations for each course (Table 2).

Descriptive statistics were conducted on the dependent variable (overall college satisfaction) and the five predictive independent variables. Table 3 displays the means, standard deviations, and minimum and maximum values for each of the predictive variables.

Bivariate correlational analyses (Table 4) were conducted to explore the associations between overall student college satisfaction and the five factors. It was found that three of the five factors: student course satisfaction, citizenship knowledge and skills, and a sense of belonging, were strongly correlated with overall student college satisfaction, with the respective Pearson's correlation values being 0.579, 0.354, and 0.537 . The frequency of student interactions was less strongly correlated with overall student satisfaction, and student awareness and resource utilization were not found to be correlated.

\subsection{Predictive Models}

4.2.1. Regression. A linear regression was generated for the five independent variables and the dependent variable (overall college satisfaction) to determine the independent variables most likely to influence overall student satisfaction.

The model summary table (Table 5 ) shows that the initial model reported an $R$ value of 0.667 and an $R$-square value of 0.445 . The $R$-square value or the coefficient of determination shows how well a model fits the data; in this case, it indicated that the five independent variables explained $44 \%$ of the variance in "overall college satisfaction." It can be seen from Table 5 that the relationship between the dependent and independent variables was statistically significant, which was also confirmed in the ANOVA table (Table 6; here, the $p$ value was less than 0.05 ).

The coefficients table (Table 7) indicated that the two variables "student course evaluation" and "a sense of belonging" were the most significant predictors of the dependent variable "overall college satisfaction."

The aforementioned multiple linear regressions were based on a continuous value for overall student satisfaction. In addition to modeling student satisfaction using linear regressions, other regression models based on 
TAвLE 3: General descriptive statistics-minimum, maximum, mean, and standard deviation.

\begin{tabular}{|c|c|c|c|c|c|}
\hline & & Minimum & Maximum & Mean & Std. deviation \\
\hline $\mathrm{Y}$ & Overall college satisfaction & 1.00 & 5.00 & 3.6333 & 0.76176 \\
\hline $\mathrm{X} 1$ & 100-level course evaluations & 1.00 & 5.00 & 3.6313 & 0.68003 \\
\hline $\mathrm{X} 2$ & Citizenship knowledge and skills & 1.00 & 5.00 & 3.3064 & 0.78447 \\
\hline $\mathrm{X} 3$ & Sense of belonging & 1.00 & 5.00 & 3.9185 & 0.75753 \\
\hline $\mathrm{X} 4$ & Student interaction & 0.00 & 3.00 & 0.6290 & 0.50215 \\
\hline $\mathrm{X} 5$ & Awareness and utilization of campus resources & 0.00 & 5.00 & 2.5794 & 1.21644 \\
\hline
\end{tabular}

TABLe 4: Pearson's correlation between overall student satisfaction and the five factors.

\begin{tabular}{|c|c|c|c|c|c|c|}
\hline & $\begin{array}{l}\text { Overall college } \\
\text { satisfaction }\end{array}$ & $\begin{array}{l}\text { 100-level course } \\
\text { evaluations }\end{array}$ & $\begin{array}{c}\text { Citizenship } \\
\text { knowledge and } \\
\text { skills }\end{array}$ & $\begin{array}{c}\text { Sense of } \\
\text { belonging }\end{array}$ & Interaction & $\begin{array}{c}\text { Awareness and utilization } \\
\text { of campus resources }\end{array}$ \\
\hline Overall college satisfaction & 1 & $0.579^{* *}$ & $0.354^{* *}$ & $0.537^{* *}$ & $0.171^{* *}$ & 0.107 \\
\hline $\begin{array}{l}\text { 100-level course } \\
\text { evaluations }\end{array}$ & $0.579^{* *}$ & 1 & $0.299^{* *}$ & $0.440^{* *}$ & $0.276^{* *}$ & 0.014 \\
\hline $\begin{array}{l}\text { Citizenship knowledge and } \\
\text { skills }\end{array}$ & $0.354^{* *}$ & $0.299^{* *}$ & 1 & $0.555^{* *}$ & $0.279^{* *}$ & 0.112 \\
\hline Sense of belonging & $0.537^{* *}$ & $0.440^{* *}$ & $0.555^{* *}$ & 1 & $0.205^{* *}$ & 0.015 \\
\hline Interaction & $0.171^{* *}$ & $0.276^{* *}$ & $0.279^{* *}$ & $0.205^{* *}$ & 1 & 0.031 \\
\hline $\begin{array}{l}\text { Awareness and utilization } \\
\text { of campus resources }\end{array}$ & 0.107 & 0.014 & 0.112 & 0.015 & 0.031 & 1 \\
\hline
\end{tabular}

Note: ${ }^{* *}$ correlation is significant at the 0.01 level (2-tailed).

TABLE 5: Model summary.

\begin{tabular}{lcccc}
\hline Model & $R$ & $\begin{array}{c}R \\
\text { square }\end{array}$ & $\begin{array}{c}\text { Adjusted } R \\
\text { square }\end{array}$ & $\begin{array}{c}\text { Std. error of the } \\
\text { estimate }\end{array}$ \\
\hline 1 & 0.667 & 0.445 & 0.434 & 0.57298 \\
\hline
\end{tabular}

Note: predictors: (constant), awareness and utilization of campus resources, 100-level course evaluations, student interaction, citizenship knowledge and skills, and sense of belonging. Dependent variable: overall college satisfaction.

TABle 6: ANOVA.

\begin{tabular}{ccccccc}
\hline & Model & Sum of squares & df & Mean square & $F$ & Sig. \\
\hline & Regression & 66.146 & 5 & 13.229 & 40.295 & 0.000 \\
1 & Residual & 82.405 & 251 & 0.328 & & \\
& Total & 148.551 & 256 & & & \\
\hline
\end{tabular}

Note: dependent variable: overall college satisfaction. Predictors: (constant), awareness and utilization of campus resources, 100-level course evaluations, student interaction, citizenship knowledge and skills, and sense of belonging.

a dichotomous dependent variable were also applied. The purpose of this step was to investigate whether the student satisfaction modeling could be further simplified and optimized. The dependent variable (Table 7) "overall student satisfaction" was transformed into a dichotomous variable with two values: 1 (less satisfied) and 2 (satisfied). When the average score was greater than 3.5, the student was classified as 2 or "satisfied"; otherwise, if the score was less than 3.5 , the student was classified as 1 or "less satisfied." Table 8 shows the number of students in each category and the associated percentages; around $45 \%$ of the students were found to be less satisfied, with $53.2 \%$ expressing satisfaction.
In this section, two supervised learning regression methods: binary logistic regression and artificial neural networks, were applied.

4.2.2. Binary Logistic Regression. Student satisfaction was modeled using binary logistic regression on IBM SPSS v. 24. Binary logistic regression is a predictive analysis used to describe data and explain the relationships between the dependent binary variable and the other independent variables. The data were examined to assess the multicollinearity between the predictors. As can be seen in the correlation matrix in Table 4, there were no high correlations found between the variables. Tabachnick and Fidell [44] suggested that the value of the correlation coefficients between independent variables should be less than 0.9 .

Table 9 presents the model summary for the logistic regression model and gives the values for the two methods used to calculate the variation: Cox and Snell $R$ square and Nagelkerke $R$ square. Based on this summary, the explained variation in the dependent variable (student overall satisfaction) ranged from $32.4 \%$ to $43.3 \%$. Many studies have preferred to report the Nagelkerke $R$-square value.

The classification table (Table 10) shows the ability of the model to predict actual outcomes, as it can be seen $77 \%$ of the outcomes were correctly predicted by the model. The note under the table states that the "cutoff value is 0.500 ," which indicates that if the probability of a case being classified in the "satisfied" category was greater than 0.500 , then that particular case was classified as "satisfied"; otherwise, the case was classified as "less satisfied."

The variation in the equation table (Table 11) shows the contribution of each independent variable to the model and the respective statistical significances, for which the Wald test 
TABLE 7: Coefficient of determination.

\begin{tabular}{|c|c|c|c|c|c|c|c|c|c|c|c|}
\hline & \multirow{2}{*}{ Model } & \multicolumn{2}{|c|}{$\begin{array}{l}\text { Unstandardized } \\
\text { coefficients }\end{array}$} & \multicolumn{3}{|c|}{$\begin{array}{l}\text { Standardized } \\
\text { coefficients }\end{array}$} & \multicolumn{3}{|c|}{ Correlations } & \multicolumn{2}{|c|}{$\begin{array}{l}\text { Collinearity } \\
\text { statistics }\end{array}$} \\
\hline & & B & $\begin{array}{l}\text { Std. } \\
\text { error }\end{array}$ & Beta & $t$ & Sig. & $\begin{array}{l}\text { Zero } \\
\text { order }\end{array}$ & Partial & Part & Tolerance & VIF \\
\hline \multirow{6}{*}{1} & Constant & 0.335 & 0.241 & & 1.388 & 0.166 & & & & & \\
\hline & 100-level course evaluations & 0.480 & 0.060 & 0.429 & 8.003 & 0.000 & 0.579 & 0.451 & 0.376 & 0.770 & 1.299 \\
\hline & Citizenship knowledge and skills & 0.039 & 0.056 & 0.040 & 0.687 & 0.493 & 0.354 & 0.043 & 0.032 & 0.653 & 1.531 \\
\hline & Sense of belonging & 0.333 & 0.061 & 0.331 & 5.489 & 0.000 & 0.537 & 0.327 & 0.258 & 0.608 & 1.645 \\
\hline & Student interaction & -0.044 & 0.076 & -0.029 & -0.578 & 0.564 & 0.171 & -0.036 & -0.027 & 0.881 & 1.135 \\
\hline & $\begin{array}{c}\text { Awareness and utilization of campus } \\
\text { resources }\end{array}$ & 0.058 & 0.030 & 0.093 & 1.954 & 0.052 & 0.107 & 0.122 & 0.092 & 0.984 & 1.016 \\
\hline
\end{tabular}

TABLE 8: Overall student satisfaction classification.

\begin{tabular}{lcccccc}
\hline Cat \# & Scale & Label & Frequency & Percent & Valid percent & Cumulative percent \\
\hline 1 & $<3.5$ & Less satisfied & 127 & 45 & 45.8 & 45.8 \\
& & Satisfied & 150 & 53.2 & 54.2 & 100.0 \\
2 & Total & 277 & 98.2 & 100.0 & \\
& & & 5 & 1.8 & & \\
& & Missing & Total & 282 & 100.0 & \\
\hline
\end{tabular}

TABle 9: Logistic regression model summary.

\begin{tabular}{cccc}
\hline Step & $-2 \log$ likelihood & $\begin{array}{c}\text { Cox and Snell } R \\
\text { square }\end{array}$ & $\begin{array}{c}\text { Nagelkerke } R \\
\text { square }\end{array}$ \\
\hline 1 & $252.087^{\mathrm{a}}$ & 0.324 & 0.433 \\
\hline
\end{tabular}

${ }^{a}$ Estimation terminated at iteration number 6 because parameter estimates changed by less than 0.001 .

("Wald" column) was used. From this table, it can be seen that the 100-level course evaluation (0.00) and sense of belonging (0.00) added significantly to the model/predictions, but that citizenship knowledge and skills (0.970), student interactions (0.101), and awareness and utilization of campus resources (0.265) did not.

\subsubsection{Artificial Neural Network (Multilayer Perceptron).} In this section, a predictive model was developed using IBM SPSS artificial neural networks, which uses nonlinear data modeling to explore the complex relationships in the data to gain greater insights.

The Multilayer Perceptron (MLP) module of IBM SPSS v. 24 was used to build the neural network model and check the prediction capacity of the five independent variables. The case-processing summary (Table 12) shows the number of cases assigned to the training sample and the number assigned to the test sample. 64.5 percent of the samples were allocated to the training set and $35.5 \%$ were allocated to the test set. The training dataset was used to determine the weights and to construct the model, and the test set was used to determine the errors and prevent overtraining during the training process.

The network information table (Table 13) gives information about the neural network, which was used to ensure all specifications were correct.

A hyperbolic tangent was used for the activation function in the hidden layer, which included three units. The network diagram generated by SPSS (Figure 2) shows the student satisfaction outcomes (less satisfied $=1$ and satisfied $=2$ ) predicted from the five factors and the five input nodes, the three hidden nodes, and the two output nodes for each student satisfaction category (less satisfied or satisfied).

The model neural network summary in Table 14 gives the training results and the application of the final network to the test sample. There were a low percentage of incorrect predictions in the training set $(21.8 \%)$ and an even lower percentage in the test set (16.5\%).

A results summary is shown in the classification table (Table 15). For the training dataset, the model was able to predict $90 \%$ of the "less satisfied" cases and $69.5 \%$ of the "satisfied" cases, with an overall correct percentage of $78.2 \%$. For the test dataset, the model was able to predict $86.7 \%$ of the "less satisfied" cases and $80.4 \%$ of the "satisfied" cases, with the overall percentage of correct cases classified in the test sample being $83.5 \%$.

Independent variable importance is a measure of the degree to which the network model is able to predict value changes for the independent variables. The normalized importance in the independent variable importance table (Table 16) was simply the importance values divided by the largest importance values and expressed as percentages, from which it can be seen that student course evaluation was the most important independent variable $(100 \%)$ in this prediction model followed by a sense of belonging (85.6\%) and student interactions $(47.8 \%)$. The analysis was based on the combined training and test samples.

\section{Discussion and Conclusion}

Various student experiences in the first-year college lay the foundation for future success and final graduation. Student perceptions about the academic, social, and environmental aspects of the college community can have a significant 
TABLE 10: Classification table.

\begin{tabular}{lccccc}
\hline & & & \multicolumn{2}{c}{ Predicted } & \\
& Observed & & Overall college satisfaction & Percentage correct \\
& & Less satisfied & Satisfied \\
\hline \multirow{2}{*}{ Step 1 } & Overall college satisfaction & Less satisfied & 80 & 35 & 69.6 \\
& Overall percentage & Satisfied & 24 & 117 & 77.0 \\
\hline
\end{tabular}

TABLE 11: Variables in the equation.

\begin{tabular}{|c|c|c|c|c|c|c|c|c|c|}
\hline & & \multirow[t]{2}{*}{$B$} & \multirow[t]{2}{*}{ SE } & \multirow[t]{2}{*}{ Wald } & \multirow[t]{2}{*}{$\mathrm{df}$} & \multirow[t]{2}{*}{ Sig. } & \multirow[t]{2}{*}{$\operatorname{Exp}(B)$} & \multicolumn{2}{|c|}{$\begin{array}{c}95 \% \text { CI for Exp } \\
(B)\end{array}$} \\
\hline & & & & & & & & Lower & Upper \\
\hline \multirow{6}{*}{ Step $1^{\mathrm{a}}$} & 100-level course evaluations & 2.013 & 0.357 & 31.712 & 1 & 0.000 & 7.483 & 3.714 & 15.077 \\
\hline & Citizenship knowledge and skills & -0.030 & 0.257 & 0.014 & 1 & 0.906 & 0.970 & 0.586 & 1.605 \\
\hline & Sense of belonging & 1.421 & 0.320 & 19.684 & 1 & 0.000 & 4.143 & 2.211 & 7.762 \\
\hline & Student interaction & -0.561 & 0.342 & 2.690 & 1 & 0.101 & 0.571 & 0.292 & 1.116 \\
\hline & Awareness and utilization of campus resources & 0.148 & 0.133 & 1.243 & 1 & 0.265 & 1.159 & 0.894 & 1.504 \\
\hline & Constant & -12.678 & 1.788 & 50.247 & 1 & 0.000 & 0.000 & & \\
\hline
\end{tabular}

${ }^{\mathrm{a}}$ Variables entered in step 1: 100-level course evaluations, citizenship knowledge and skills, sense of belonging, student interaction, and awareness and utilization of campus resources.

TABLE 12: Case-processing summary.

\begin{tabular}{|c|c|c|c|}
\hline & & $N$ & Percent \\
\hline \multirow{2}{*}{ Sample } & Training & 165 & 64.5 \\
\hline & Testing & 91 & 35.5 \\
\hline Valid & & 256 & 100.0 \\
\hline Excluded & & 26 & \\
\hline Total & & 282 & \\
\hline
\end{tabular}

impact on overall college experiences. Using IBM SPSS v. 24, data from a developed questionnaire were explored and analyzed, and bivariate correlations, linear regressions, and artificial neural networks were employed to determine the relationships and the capabilities of these factors to predict overall student college satisfaction.

It was found that student perceptions of the academic, social, and environmental aspects were positively correlated with overall satisfaction with the college experience. The regression analyses found that the students were satisfied with the quality of their first-year experience when the courses offered assisted them in adapting to college life, helped them participate in social and academic activities, increased their motivation, and improved their academic skills. This finding was consistent with studies conducted by Mai [45], Douglas et al. [46], and Gibson [47]. Douglas et al. [46] concluded that the most critical factors related to student satisfaction were those associated with the quality of teaching and learning. Similarly, Gibson [47] found that academic aspects such as teaching and learning quality were the most significant determinants of overall student satisfaction.

The other factor that was found to be highly correlated with overall student college satisfaction was students' sense of belonging. Feeling part of the college community was found to contribute significantly to student satisfaction, which supported studies by Thomas and Galambos [34], Billups [17], Gibson [47], and Fleming et al. [33]. Billups [17] demonstrated that one of the best predictors for student satisfaction and retention was the "student's identification and integration with the campus community" (p. 13). Similarly, Gibson [47] found that noncognitive factors such as students' feelings of belonging contributed significantly to overall satisfaction. Course effectiveness and sense of belonging were also confirmed by Elliott and Healy [1], who found that "student centeredness," "campus climate," and "instructional effectiveness" had a significant impact on the overall student satisfaction with their educational experiences.

The third factor was student citizenship knowledge and skills. Knowledge about the local community and the training and research opportunities available were found to contribute to feelings of satisfaction with the first-year college experience. The more the knowledge about the society, the nation, and the world the student had, the more positive their views toward higher education. In contrast to previous studies, student interactions and student resource awareness and utilization were found to be less correlated with the overall student college experience, which was in contrast to findings by Astin [48] and by Endo and Harpel [36].

The fifth factor, student awareness and utilization of campus resources, was found to have less predictive power than the other factors. While this finding was consistent with that by Mariani et al. [49] and Thomas and Galambos [34], it was contrary to that by Hanssen and Solvoll [15] and Nasser et al. [38].

The five factors were found to contribute $44 \%$ to the variance in overall student satisfaction with the first-year college experience. The binary logistics regression revealed an overall predictive accuracy of $77 \%$, with student course 
TABLE 13: Network information.

\begin{tabular}{|c|c|c|c|}
\hline \multirow{7}{*}{ Input layer } & \multirow{5}{*}{ Covariates } & 1 & 100-level course evaluation \\
\hline & & 2 & Citizenship knowledge and skills \\
\hline & & 3 & Sense of belonging \\
\hline & & 4 & Student interaction \\
\hline & & 5 & Awareness and utilization of campus resources \\
\hline & \multirow{2}{*}{\multicolumn{2}{|c|}{$\begin{array}{c}\text { Number of units }{ }^{\mathrm{a}} \\
\text { Rescaling method for covariates }\end{array}$}} & 5 \\
\hline & & & Standardized \\
\hline \multirow{3}{*}{ Hidden layer(s) } & \multirow{3}{*}{\multicolumn{2}{|c|}{$\begin{array}{l}\text { Number of hidden layers } \\
\text { Number of units in hidden layer } 1^{\mathrm{a}} \\
\text { Activation function }\end{array}$}} & 1 \\
\hline & & & 3 \\
\hline & & & Hyperbolic tangent \\
\hline \multirow{4}{*}{ Output layer } & Dependent variables & 1 & Overall college satisfaction \\
\hline & Number o & & 2 \\
\hline & Activation & & Softmax \\
\hline & Error fur & & Cross-entropy \\
\hline
\end{tabular}

${ }^{a}$ Excluding the bias unit.

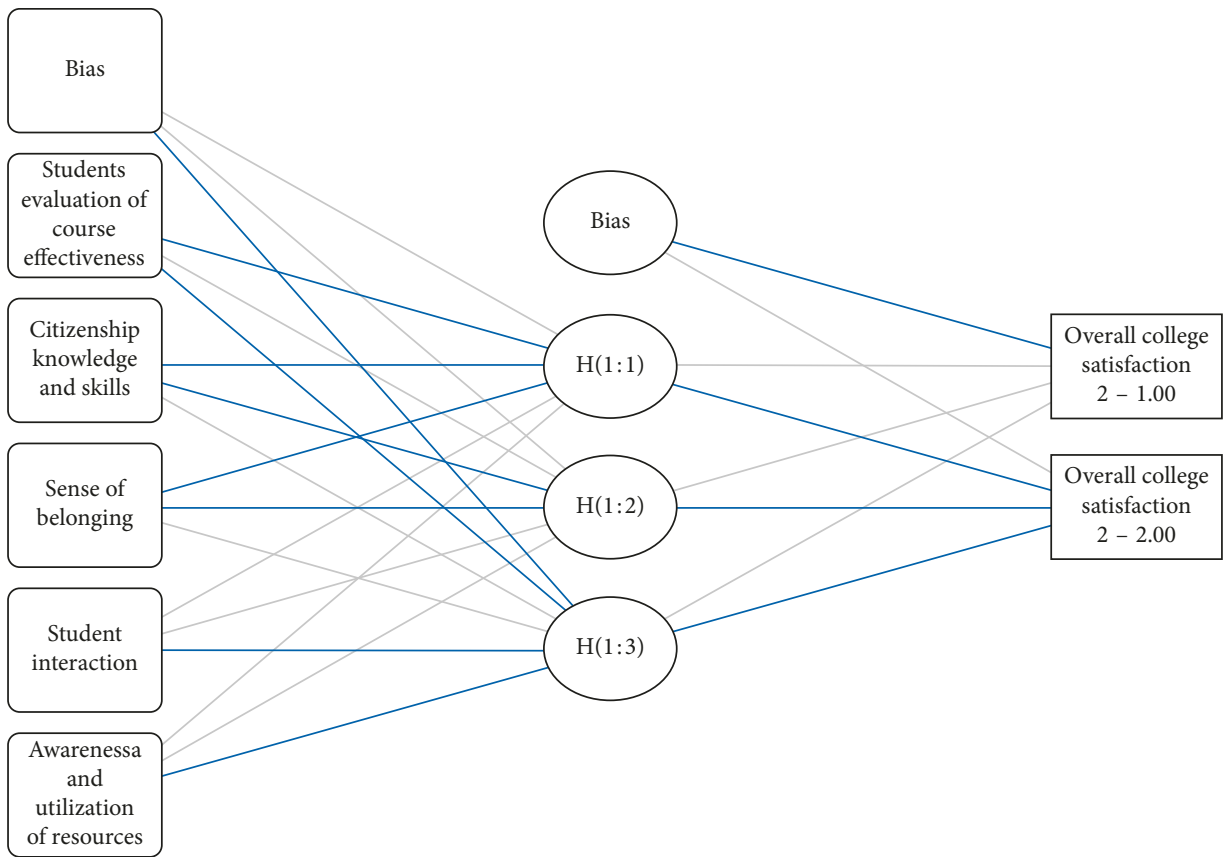

Hidden layer activation function: hyperbolic tangent

Output layer activation function: softmax

Synaptic weight $>0$

Synaptic weight $<0$

Figure 2: Network diagram.

TABLE 14: Model summary for the neural network results.

$\begin{array}{ll}\text { Cross-entropy error } & 71.055\end{array}$

Training Percent incorrect predictions

Stopping rule used

Training time

1 consecutive step with no decrease in error ${ }^{\mathrm{a}}$

Cross-entropy error 0:00:00.07

Testing Percent incorrect predictions

37.224

Note: dependent variable: overall college satisfaction. ${ }^{a}$ Error computations are based on the testing sample.

satisfaction and sense of belonging being the best determinants of overall student satisfaction. The artificial neural network results further confirmed these significant correlations and the prediction capacities of the investigated factors. In the training dataset, the multilayer perceptron model showed the capabilities of the five factors to predict "satisfied" and "less satisfied" students with an accuracy rate of $78.2 \%$ for the training sample and $83.5 \%$ for the test 
TABLE 15: Classification table.

\begin{tabular}{|c|c|c|c|c|}
\hline \multirow{2}{*}{ Sample } & \multirow{2}{*}{ Observed } & \multicolumn{3}{|c|}{ Predicted } \\
\hline & & Less satisfied & Satisfied & Percent correct \\
\hline \multirow{3}{*}{ Training } & Less satisfied & 63 & 7 & 90.0 \\
\hline & Satisfied & 29 & 66 & 69.5 \\
\hline & Overall percent & 55.8 & 44.2 & 78.2 \\
\hline \multirow{3}{*}{ Testing } & Less satisfied & 39 & 6 & 86.7 \\
\hline & Satisfied & 9 & 37 & 80.4 \\
\hline & Overall percent & 52.7 & 47.3 & 83.5 \\
\hline
\end{tabular}

Dependent variable: overall college satisfaction.

TABLE 16: Independent variable importance.

\begin{tabular}{lcc}
\hline & Importance & Normalized importance (\%) \\
\hline 100-level course evaluations & 0.360 & 100.0 \\
Citizenship knowledge and skills & 0.055 & 15.4 \\
Sense of belonging & 0.308 & 85.6 \\
Student interaction & 0.172 & 47.8 \\
Awareness and utilization of campus resources & 0.105 & 29.3 \\
\hline
\end{tabular}

sample, with the normalized importance chart indicating that student course satisfaction was the most important factor in this model, followed by the students' sense of belonging. Based on the overall prediction accuracy value, it was concluded that the artificial neural network outperformed the binary logistic regression. Elliot and Shin [42] claimed that "focusing on student satisfaction not only enables universities to reengineer their organizations to adapt to student needs but also allows them to develop a system for continuously monitoring how effectively they meet or exceed student needs." Grebennikov and Shah [50] suggested that student satisfaction data could be utilized by institutions to further enhance their high-performing areas as well as to highlight those areas needing improvement. They further proposed that taking a systematic approach to student feedback and acting quickly on the results could substantially strengthen student involvement and satisfaction.

This study indicated that overall student college satisfaction could be improved by enhancing those elements that could change students' attitudes and perceptions and make them feel happier and more satisfied with their overall firstyear experiences. In this case, more emphasis needs to be given to the learning experiences offered through the 100level courses, and these courses should continue to enhance their content and delivery. Some important elements under the course satisfaction factor were encouraging students to participate in academic and social activities and assisting students to improve their writing, presentation, career, and time management skills.

5.1. Recommendations and Future Research. These student survey results can be used to identify areas of strength and weakness in the first-year student experience. The results related to student satisfaction can also assist college leaders in setting appropriate goals and prioritizing initiatives for first-year students. Several steps are recommended based on the results: extending student orientation sessions, organizing more support service department workshops and training sessions, developing first-year seminars into more specialized courses, and providing professional development opportunities for the faculty members who are teaching first-year students.

An area for future research is to further explore the influence of other personal and attitudinal factors on students' perceptions and satisfaction with the quality of their college experience and whether these associations differ by gender.

\section{Data Availability}

The data used to support the findings of this study are available from the corresponding author upon request.

\section{Conflicts of Interest}

The authors declare that they have no conflicts of interest.

\section{References}

[1] K. Elliott and M. Healy, "Key factors influencing student satisfaction related to recruitment and retention," Journal of Marketing for Higher Education, vol. 10, no. 4, pp. 1-11, 2001.

[2] S. Aldridge and J. Rowley, "Measuring customer satisfaction in higher education," Quality Assurance in Education, vol. 6, no. 4, pp. 197-204, 1998.

[3] J. Bryant and S. Bodfish, "The relationship of student satisfaction to key indicators for colleges and universities," 2014 National Research Report, Noel-Levitz, Inc., Cedar Rapids, IA, USA, 2014.

[4] B. Browne, D. Kaldenberg, W. Browne, and D. Brown, "Student as customer: factors affecting satisfaction and assessments of institutional quality," Journal of Marketing for Higher Education, vol. 8, no. 3, pp. 1-14, 1998.

[5] A. Athiyaman, "Linking student satisfaction and service quality perceptions: the case of university education," European Journal of Marketing, vol. 31, no. 7, pp. 528-540, 1997. 
[6] G. Hampton, "Gap analysis of college student satisfaction as a measure of professional service quality," Journal of Professional Services Marketing, vol. 9, no. 1, pp. 115-128, 1993.

[7] H. Hasan, A. Ilias, R. Rahman, and M. Razak, "Service quality and student satisfaction: a case study at private higher education institutions," International Business Research, vol. 1, no. 3, 2009.

[8] L. Petruzzellis, A. M. D’Uggento, and S. Romanazzi, "Student satisfaction and quality of service in Italian universities," Managing Service Quality: An International Journal, vol. 16, no. 4, pp. 349-364, 2006.

[9] M. Marzo Navarro, M. Pedraja Iglesias, and P. Rivera Torres, "A new management element for universities: satisfaction with the offered courses," International Journal of Educational Management, vol. 19, no. 6, pp. 505-526, 2005.

[10] K. Elliott, "Key determinants of student satisfaction," Journal of College Student Retention: Research, Theory and Practice, vol. 4, no. 3, pp. 271-279, 2002.

[11] V. Tinto, Leaving College: Rethinking the Causes and Cures of Student Attrition, University of Chicago Press, Chicago, IL, USA, 1987.

[12] C. B. Schertzer and S. M. Schertzer, "Student satisfaction and retention: a conceptual model," Journal of Marketing for Higher Education, vol. 14, no. 1, pp. 79-91, 2004.

[13] B. O. Barefoot, "Current institutional practices in the first college year," in Challenging and Supporting the First Year Student: A Handbook for Improving the First Year, M. Upcraft, J. Gardner, and B. Barefoot, Eds., Wiley, Hoboken, NJ, USA, 2005.

[14] P. G. Schrader and S. W. Brown, "Evaluating the first year experience: students' knowledge, attitudes, and behaviors," Journal of Advanced Academics, vol. 19, no. 2, pp. 310-343, 2008.

[15] T. Hanssen and G. Solvoll, "The importance of university facilities for student satisfaction at a Norwegian University," Facilities, vol. 33, no. 13-14, pp. 744-759, 2015.

[16] D. Hartman and S. Schmidt, "Understanding student/alumni satisfaction from a consumer's perspective: the effects of institutional performance and program outcomes," Research in Higher Education, vol. 36, no. 2, pp. 197-217, 1995.

[17] F. D. Billups, "Measuring college student satisfaction: a multiyear study of the factors leading to persistence," in Proceedings of Northeast Educational Research Association Annual Conference, Rocky Hill, CT, USA, October 2008.

[18] R. Styron Jr., "Student satisfaction and persistence: factors vital to student retention," Research in Higher Education Journal, vol. 6, p. 1, 2010.

[19] M. Oja, "Student satisfaction and student performance," Journal of Applied Research in the Community College, vol. 19, no. 1, pp. 47-53, 2011.

[20] M. K. Dhaqane and N. A. Afrah, "Satisfaction of students and academic performance in Benadir university," Journal of Education and Practice, vol. 7, no. 24, pp. 59-63, 2016.

[21] J. Bean and R. Bradley, "Untangling the satisfactionperformance relationship for college students," Journal of Higher Education, vol. 57, no. 4, p. 393, 1986.

[22] T. Gruber, S. Fuß, R. Voss, and M. Gläser-Zikuda, "Examining student satisfaction with higher education services: using a new measurement tool," International Journal of Public Sector Management, vol. 23, no. 2, pp. 105-123, 2010.

[23] B. Z. Butt and K. ur Rehman, "A study examining the students satisfaction in higher education," Procedia-Social and Behavioral Sciences, vol. 2, no. 2, pp. 5446-5450, 2010.
[24] L. Temizer and A. Turkyilmaz, "Implementation of student satisfaction index model in higher education institutions," Procedia-Social and Behavioral Sciences, vol. 46, pp. 38023806, 2012.

[25] S. Alam Malik, S. Hassan, and M. Zahid Iqbal, "Measuring students' perceptions and expectations in business schools of Pakistan," Asian Education and Development Studies, vol. 1, no. 3, pp. 222-236, 2012.

[26] S. K. Parahoo, H. L. Harvey, and R. M. Tamim, "Factors influencing student satisfaction in universities in the Gulf region: does gender of students matter?," Journal of Marketing for Higher Education, vol. 23, no. 2, pp. 135-154, 2013.

[27] Z. Yang, B. Becerik-Gerber, and L. Mino, "A study on student perceptions of higher education classrooms: impact of classroom attributes on student satisfaction and performance," Building and Environment, vol. 70, pp. 171-188, 2013.

[28] J. A. Douglas, A. Douglas, R. J. McClelland, and J. Davies, "Understanding student satisfaction and dissatisfaction: an interpretive study in the UK higher education context," Studies in Higher Education, vol. 40, no. 2, pp. 329-349, 2015.

[29] E. A. Bates, L. K. Kaye, and J. J. McCann, "A snapshot of the student experience: exploring student satisfaction through the use of photographic elicitation," Journal of Further and Higher Education, pp. 1-14, 2017.

[30] A. P. Frederick, "Preparing students for lives of responsible citizenship: a higher education civic Blueprint for the state of New Jersey," Dissertation and Thesis, 2007.

[31] T. L. Strayhorn, College Students' Sense of Belonging: A Key to Educational Success for All Students, Routledge, Abingdon, UK, 2012.

[32] S. Hurtado and D. Carter, "Effects of college transition and perceptions of the campus racial climate on Latino college students; sense of belonging," Sociology of Education, vol. 70, no. 4, p. 324, 1997.

[33] A. Fleming, K. Oertle, A. Plotner, and J. Hakun, "Influence of social factors on student satisfaction among college students with disabilities," Journal of College Student Development, vol. 58, no. 2, pp. 215-228, 2017.

[34] E. H. Thomas and N. Galambos, "What satisfies students? Mining student-opinion data with regression and decision tree analysis," Research in Higher Education, vol. 45, no. 3, pp. 251-269, 2004.

[35] C. W. Yao, Sense of Belonging in International Students: Making the Case against Integration to US Institutions of Higher Education, Vol. 45, Faculty Publications in Educational Administration, USA, 2015.

[36] J. Endo and R. Harpel, "The effect of student-faculty interaction on students' educational outcomes," Research in Higher Education, vol. 16, no. 2, pp. 115-138, 1982.

[37] P. T. Terenzini and E. T. Pascarella, "Student/faculty relationships and freshman year educational outcomes: a further investigation," Journal of College Student Personnel, vol. 21, no. 6, pp. 521-528, 1980.

[38] R. N. Nasser, B. Khoury, and K. Abouchedid, "University students' knowledge of services and programs in relation to satisfaction: a case study of a private university in Lebanon," Quality Assurance in Education, vol. 16, no. 1, pp. 80-97, 2008.

[39] A. Astin, What Matters in College?, Jossey-Bass, San Francisco, CA, USA, 1993.

[40] V. Tinto, Leaving College: Rethinking the Causes and Cures of Student Attrition, University of Chicago Press, Chicago, IL, USA, 1993.

[41] J. Burtner, "Critical-to-quality factors associated with engineering student persistence: the influence of freshman 
attitudes," in Proceedings of 34th Annual Frontiers in Education, IEEE, Savannah, GA, USA, October 2004.

[42] K. Elliott and D. Shin, "Student Satisfaction: an alternative approach to assessing this important concept," Journal of Higher Education Policy and Management, vol. 24, no. 2, pp. 197-209, 2002.

[43] R. A. Sevier, Those Important Things: What Every College President Needs to Know about Marketing and Student Recruiting, College and University, Spring, Washington, DC, USA, 1996.

[44] B. G. Tabachnick and L. S. Fidell, Using Multivariate Statistics, Pearson, Essex, UK, 6th edition, 2014.

[45] L. Mai, "A comparative study between UK and US: the student satisfaction in higher education and its influential factors," Journal of Marketing Management, vol. 21, no. 7-8, pp. 859878, 2005.

[46] J. Douglas, A. Douglas, and B. Barnes, "Measuring student satisfaction at a UK university," Quality Assurance in Education, vol. 14, no. 3, pp. 251-267, 2006.

[47] A. Gibson, "Measuring business student satisfaction: A review and summary of the major predictors," Journal of Higher Education Policy and Management, vol. 32, no. 3, pp. 251-259, 2010.

[48] A. W. Astin, "Student involvement: a developmental theory for higher education," Journal of College Student Personnel, vol. 25, no. 4, pp. 297-308, 1984.

[49] P. Mariani, E. Rancati, and N. Gordini, "Student satisfaction in higher education: empirical evidence from university of Milano-Bicocca," in Proceedings of Toulon-Verona Conference Excellence in Services, Palermo, Italy, 2015.

[50] L. Grebennikov and M. Shah, "Monitoring trends in student satisfaction," Tertiary Education and Management, vol. 19, no. 4, pp. 301-322, 2013. 


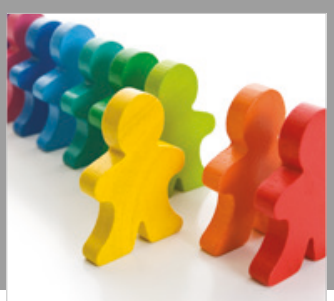

Autism

Research and Treatment
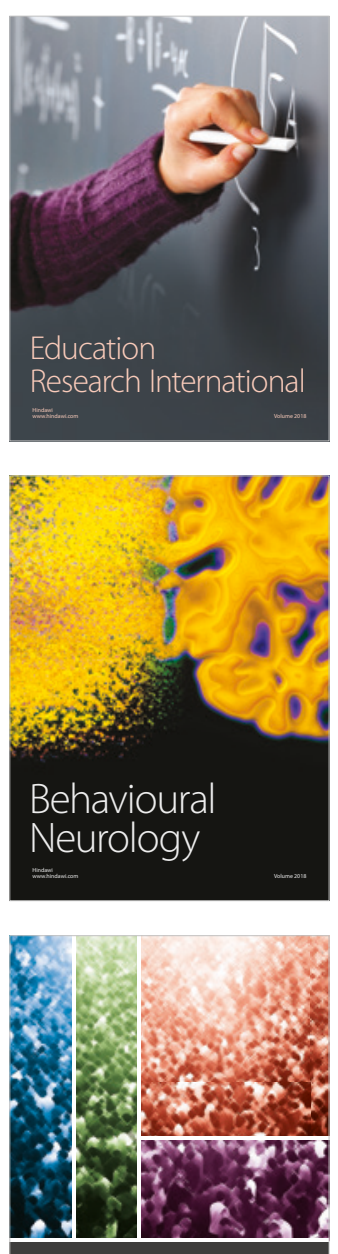

International Journal of

Population Research

$\underline{-m}$

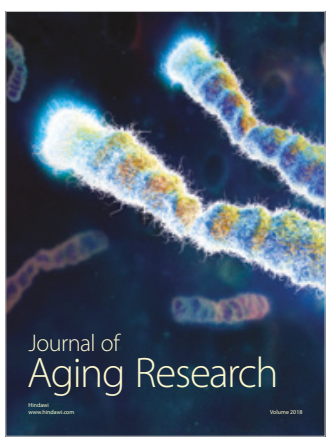

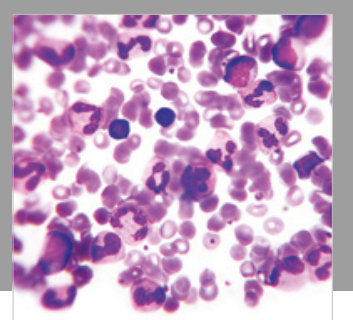

Pathology

Research International$$
=
$$

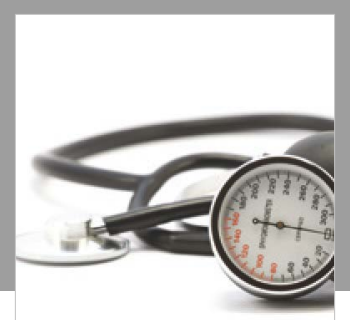

Nursing

Research and Practice

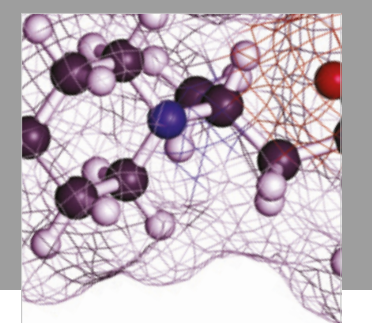

Pain

Research and Management

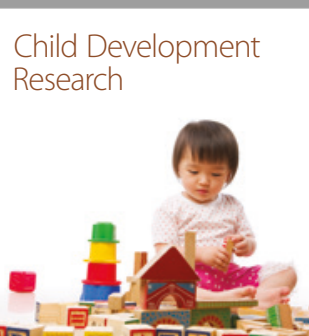

बाD

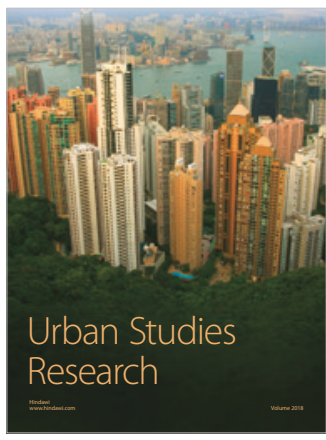

\section{Hindawi}

Submit your manuscripts at

www.hindawi.com
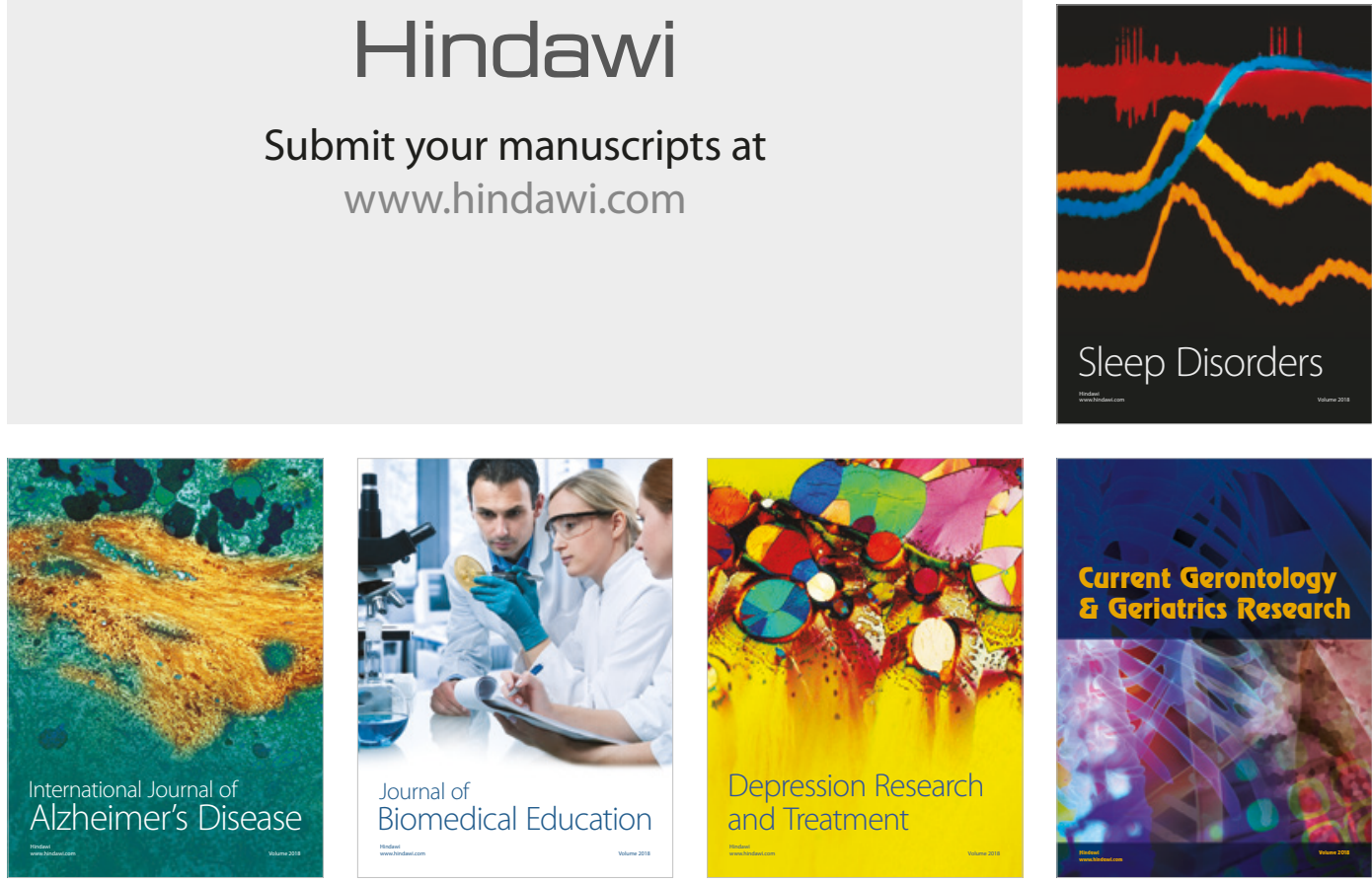

Journal of

Biomedical Education

$=$

smman

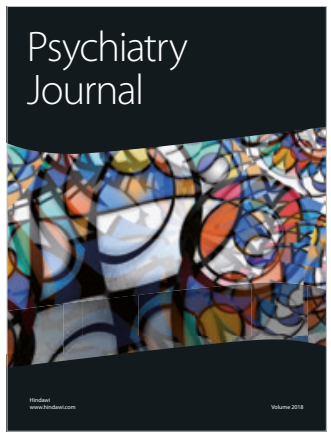

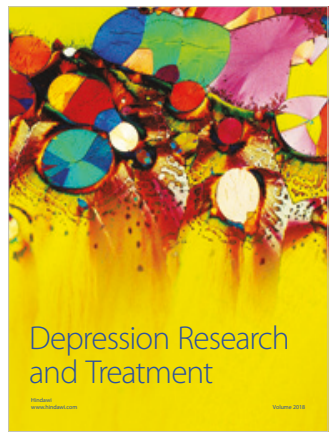
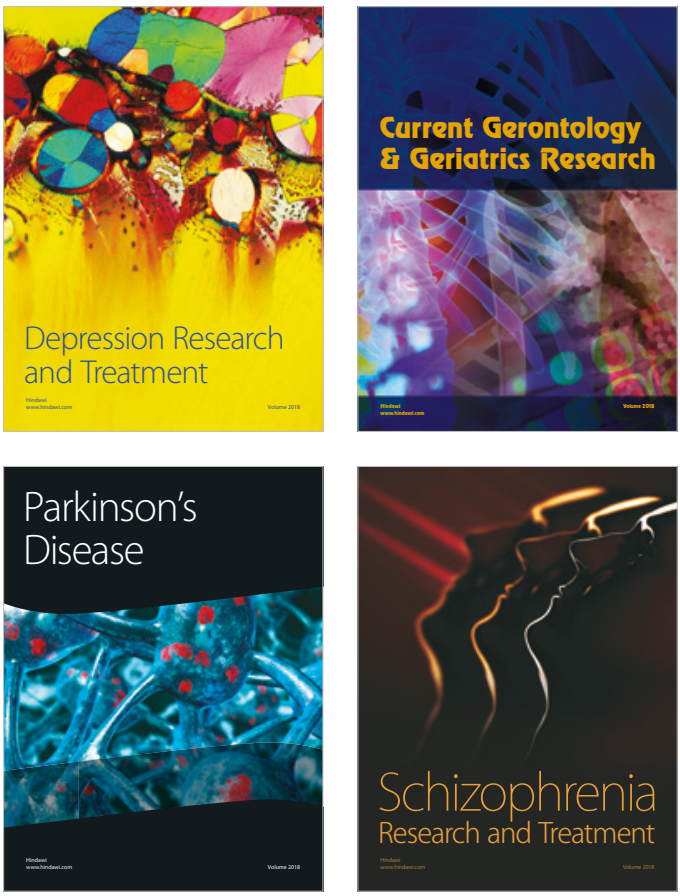